\title{
Pathways to early retirement: structure and agency in decision-making among British civil servants
}

\author{
PAUL HIGGS*, GILL MEIN $\dagger$, JANE FERRIE $\dagger$, MARTIN HYDE $\dagger$ \\ and JAMES NAZROO $\dagger$
}

\begin{abstract}
The context of this paper is the changing nature of later life in the United Kingdom. It examines some of the broader issues of early retirement. While there has been considerable debate about the restructuring of employment during the latter part of the 2oth century which led to a shake-out of older workers from the labour force, less attention has been given to those who take voluntary early retirement. Given the importance of early retirement to the economy and to social policy, it is important to find out how individuals make retirement decisions. The paper examines the results of a semi-structured interview study of the decisions made by a purposively drawn sample of British civil servants who are participants in the Whitehall II study. The sample included participants who chose early retirement and those who did not. From the interview data, ideal types of possible routes into retirement have been constructed. Illustrating these ideal types, individual life histories are drawn upon to show how responses to the issues surrounding retirement feature in people's lives. It is argued that decisions about early retirement are not made in a vacuum, neither are they free from pressures or inducements. Some are to do with organisational restructuring, some are about financial offers, and some are influenced by the opportunities for leisure and self-fulfilment that early retirement offers. The paper concludes by arguing that early retirement needs to be studied as a process involving the interplay between structure and agency.
\end{abstract}

$\boldsymbol{K E Y} \boldsymbol{W O R D S}$ - early retirement, structure and agency, qualitative research.

\section{Background}

For most of the 2oth century, retirement from the workforce represented an important transition into old age. A key marker in the United Kingdom

* Centre for Behavioural and Social Sciences in Medicine, University College London.

$\dagger$ Department of Epidemiology and Public Health, University College London. 
has been the state retirement age, which has varied over time and between men and women. In the past it was set at 70 years for men, while currently it is 65 years for men and 60 years for women. The age for women will rise to 65 years by 2020 . During much of the last century, many assumed that life after leaving the workforce would be bound up with infirmity and decline: indeed, it was a justification for retirement. As a result, being retired had primarily a negative status (Townsend ig8I; Walker I981). During the 1980 , there was evidence that some older workers were being made redundant in their late fifties and early sixties and were never expected to work again (Laczko and Phillipson I99I). These 'early exit' workers were treated as if they were already retired, even though they had not reached the statutory retirement age. Retirement, whenever it occurred, was seen as a marker of a decline in social position, income and health. This negative conclusion can be contrasted with the more positive assessments made by Peter Laslett, who argued that many affluent whitecollar workers approached life after work as a period for leisure and selffulfilment (Laslett I989; see also Blaikie ı999; Phillipson ı999; Higgs I999; Gilleard and Higgs 2000; King, Warnes and Williams 2000). In these writings, later life is identified as a period of opportunities, not of inevitable decline and dependency. The alternative representations have coincided with increases in life expectancy and improvements in the health of the older population. The connection between leaving the workforce and dependency (whether physical or financial) is no longer axiomatic; instead, there is now at least the promise of a 'third age'. Individual trajectories of retirement represent the outcome of these now varied social and personal pressures. This paper seeks to examine some of these issues, using a qualitative study of British civil servants.

\section{The civil service}

The civil service is one of the largest employers in the United Kingdom. In I999, it had 460,000 staff, down from the 732,000 staff employed in 1979 (Government Statistical Service i999). The civil service was for long immune from the direct pressures of the market place: it offered job security and good conditions of service. Much of this changed during the I980s, however, when the public sector was subject to challenges from the private sector (Foster and Plowden 1996). A I986 report, Using Private Enterprise in Government, recommended an examination of all government work to determine whether it could be improved by transfer to the private sector or abolished altogether (National Union of Civil and Public Servants I99I). By the end of 1997, many public utilities had been privatised, and 
privatisation was being introduced into health care, education and local government. The civil service was not immune, for some parts were privatised, such as the Property Services Agency (PSA), and it experienced staff reductions through redundancies and early retirements. A sense of job insecurity spread throughout the service.

At that time, employees approaching the end of their careers were offered enhanced financial packages to encourage them to retire earlier than the mandatory civil service retirement age of 60 years. Some who accepted the packages retired from work altogether, while others took the opportunity to work outside the civil service. During the period of the research, retirement at 60 years was the upper age limit for employment for a civil servant, although some continued longer if their job was regarded as essential or if they had insufficient years of service to be eligible for a (full) pension. The civil service pension is based upon years of service and employment grade on departure. Civil servants with 40 years service should receive a pension equivalent to about half their final salary. Departments are responsible for paying the pensions of their own staff, except that if retirement is on medical grounds The Treasury meets the cost. Consequently, not only is medical retirement a health issue, it is also one of financial responsibility. In addition, the pension of an employee who is medically retired may be higher than an ordinary pension (to allow for medical care costs).

\section{Methods}

The Whitehall II study began in 1985 (Marmot et al. 199I). All employees aged between 35 and 55 years in 20 London-based civil service departments were invited to participate. Since 1985 the study has collected from the panel of participants information on personal characteristics, health, work circumstances, social life, family and relationships, as well as physiological and health-related data.

The analysis reported here uses a group of 6o participants from the Whitehall II study who participated in semi-structured interviews about retirement issues (Mein et al. 1998, 2000). Participants were over 55 years old and had variously taken early retirement, retired at the normal age, or were still working. Respondents for the interviews were purposively selected, by retirement status (still working, normal or early retirement), occupational grade (administrative, professional/executive, or clerical/ support) and gender. Respondents were also selected by marital status, accommodation arrangements (living alone or with others), and presence or absence of long-standing illness. 
The topic guide for the semi-structured interviews was based on findings from a focus group, which was held with eight civil servants who were at different stages of the retirement (or early retirement) process, and who discussed some issues that arose from a literature search. The topic guide contained questions that took people through their work history and the process of retirement. This included their history of work in the civil service, planning for retirement, present experiences of work and retirement, and expectations of their future as a retired person. They were further asked how they had prepared for their retirement and why they had decided to retire at a particular time. Individuals who had retired were asked to describe what changes they had experienced since retirement in their income, health, diet and lifestyle, and how these changes had affected them. Participants were asked to describe or recall their pre-retirement expectations and, if appropriate, to expand on how their present experiences in retirement matched those expectations. The retired respondents were also questioned about how they felt they were coping and adjusting to retirement and, finally, about the advice that they would give to others about to retire. ${ }^{1}$

To organise the material from the interviews, the concept of 'ideal types' (associated with the Weberian tradition of interpretive sociology) was utilised as a form of 'classificatory abstraction'. As Becker (I998) wrote, in the ideal type an 'idealised' version of reality is constructed in order to emphasise essential features. We have followed this approach in examining the issue of early exit from or remaining in the civil service. Using a template of the choices about retirement that the respondents made (or intended to make), seven ideal types were created (Table I). These have been described and contextualised using the data from individuals' responses to elucidate the interplay between structure and agency.

\section{Ideal types of early retirement decisions}

\section{Financially attached to work}

Some civil servants remained in the service until the mandatory age of retirement because they could not afford to retire earlier, some specifically to ensure they had a fully-funded occupational pension. Others had particular financial commitments, such as school or college fees for their children, non-working spouses, or elderly relatives. Typically, such individuals would not have sought, nor have been offered, a sufficiently attractive financial package for early retirement. One example was Mrs A (59 years), who had worked in the professional grade for 29 years. She had 
T A B L E I. Ideal types of early retirement decisions

\begin{tabular}{|c|c|}
\hline Ideal type & Characteristic or attribute \\
\hline & Remains working because: \\
\hline Financially attached to work & Has financial commitments, needs fully funded pension \\
\hline Enjoys work & $\begin{array}{l}\text { Is satisfied with work, difficult circumstances at home, } \\
\text { lack of a non-work role }\end{array}$ \\
\hline Traditional work ethic & $\begin{array}{l}\text { Believes one works until normal retirement age, could afford } \\
\text { to leave work, does not question leaving early }\end{array}$ \\
\hline Financial exit & $\begin{array}{l}\text { Leaves work because: } \\
\text { Has been offered an early retirement package, the benefits of } \\
\text { the package outweigh the benefits of staying at work, } \\
\text { has a fully-funded pension }\end{array}$ \\
\hline Third Age exit & $\begin{array}{l}\text { Has been offered an early retirement package, have reasons } \\
\text { outside work environment to encourage leaving }\end{array}$ \\
\hline Work dissatisfaction exit & Dislikes job or changes within civil service \\
\hline Poor health exit & Illness or disability of self or dependent \\
\hline
\end{tabular}

been divorced for io years and had had many financial problems associated with mortgage repayments on her home after the divorce. Her options for retirement were limited by gaps in her pension contribution record, for she had stayed at home to look after her children for i3 years. She was also affected by having been a 'working married woman', which for several years prevented her contributing to the civil service occupational pension scheme. ${ }^{2}$ Consequently she was worried how she would cope financially when retired. Mrs A hoped that by staying at work until 60 years of age, and by making additional pensions contributions, she would not have to work when she retired:

If finances get fraught I might look around locally, but I am not planning to doing any high-powered work of any sort; I would just look for something to supplement the income if need be. But I hope I don't need to.

Another example, less structured by gender, was provided by $\mathrm{Mr} \mathrm{J}$, a senior civil servant who was aged 59 years when interviewed. He intended to retire at the mandatory age of 60 years although he would have preferred to remain employed until he was 63 years. He had been offered a 'quite attractive' early retirement package, but chose not to accept it. $\mathrm{Mr} \mathrm{J}$ also illustrated the impact that high incomes have on retirement decisions. He needed to keep at work partly because he had two financially-dependent children at university, but also because he enjoyed the standard of life that his salary gave him.

I'll be putting the lad through three years at university. Come on, my pension as a senior civil servant, there's my wife working, there are people putting children through university that earn a damn sight less than I will get for my pension, so 
I've got to get this into perspective. On the other hand, I'd still like to maintain something of the standard of living to which I've become accustomed.

\section{Enjoys work}

The second ideal type characterises the respondents who reported that they were staying at work because they found working in the civil service engaging. One example was Mr B (59 years), who had worked in an administrative grade for 40 years. He had had a varied career that had included overseas posts, and described his current job as 'brilliant' and his whole career as 'outstanding'. He said, 'I've been paid to do my hobby every time'. Strongly hoping that he would still be involved with his job voluntarily after he had retired, he was not negative about retirement, which he looked upon as an opportunity to do other things. He was not driven by the financial consequences of retirement, as he believed that the fall in income would not significantly alter his quality of life. He had not considered taking early retirement, for he could think of nothing that had given him as much pleasure as his job.

Some individuals described difficult or challenging circumstances at home that made the workplace attractive. Several of the interviewees were worried about spending more time with their spouses after their retirement. Mrs B chose to stay working because she enjoyed her work, and when she retired she would be the principal carer of her chronically sick husband. Mr A claimed that he did not know how he would manage without employment, as work was such an important part of his life.

My apprehension was that I wasn't going to be as happy retired as I was working because I enjoyed work. It was just [that] I felt that life was not so satisfying without work, because work had become a big part of my life.

Typically, these individuals remained working until the mandatory retirement age (and many expressed the hope that they would be able to continue working beyond this age) even though they were financially secure enough to retire early.

\section{Traditional work ethic}

This group comprised those who simply did not contemplate leaving work before the mandatory age of retirement, despite having the opportunity even of a full pension. Typically they viewed their work as the main part of their life, and saw early retirement as only appropriate in cases of ill-health, disability or misfortune. Mr C retired at the mandatory time 
following $3^{8}$ years in the professional grade. He was single and lived alone. Following a re-organisation before his retirement, his job was expunged. He described his hurt feelings as he learnt from a friend that his speciality was being phased out, and he said, 'the work I was doing all those years had been virtually quashed'. Despite this, he did not consider early retirement because he believed that the 'usual' age of retirement was 6o years. He accepted a transfer to an administrative job away from his speciality. Mr $\mathrm{C}$ was not worried about his income and had not had financial problems since he had retired. He was stoical about retirement: 'I was 6o and that's when they push you out, you see'. He summarised his approach: 'So you just fall in place. You're 6o, you retire, and there's no discussion'.

\section{Financial exit}

This ideal type describes a group who left the civil service with early retirement payouts, and a few who continued working after they had left. Many left because of the inducements, some because they had financial commitments, such as a mortgage or dependent children, that the package solved. Mrs D (58 years), a senior civil servant, was offered at 57 years of age a very generous financial package, including a bonus, to leave the civil service with help to complete her occupational pension. She happily accepted this, and readily stated that it was 'the size of the package' that influenced her decision. Like many women who had taken time off from paid work to look after children, she needed to make up years of pension contributions. She explained: 'So I started buying the years, well, really quite late, so as soon as the package came along, and they agreed to make up, well, they made up six years'. After taking early retirement she set up her own consultancy business so that 'I could earn enough money with the pension I get for the next few years and then I shall gracefully retire altogether'.

Although the offered financial packages were not always large, they were a sufficient incentive for those capable of, or hoping to find, other paid work outside the civil service after (early) retirement. Some participants planned to work following retirement. Mr E, a civil service messenger, had accepted the early retirement financial package because he needed cash for a mortgage.

Well, in the end I was working it out, so I took early retirement. I took as much cash as possible ... I don't get my pension until I'm 6o, I took it in cash instead you see, in cash in lieu, so I got a lot of cash out. Well I got, 'cause I ain't no money then, you see, when I come out, still spending all my money I was. 
He also knew that he had to continue working for several more years because his mortgage would close when he was 75 years old. Consequently at the time of interview he worked as a security guard.

\section{'Third age' exit}

This ideal type describes those who took early retirement to become more involved in outside interests and hobbies. Instances included involvement with voluntary groups and charitable work, spending more time with relatives and friends, pursuing hobbies or relaxing. Individuals in this group were likely to be dissatisfied with their job and to see no reason to continue working. Unlike the 'financial exit' group, however, they mainly wanted to leave work because there were many things that they wished to do. The offer of a good early retirement financial package meant that they could afford to retire early and do those things.

Mrs I, for example, a married woman who had worked in the civil service for 22 years, had refused promotion because it was to a more demanding position and she did not want her life to revolve around work. She had wanted a job that she could cope with, to work with people she enjoyed, and just to go home at the end of the day to do her country dancing. Mrs I said she was not a 'career person'. She started job sharing to reduce her hours at work, but was not very happy with the arrangement and decided to retire early. Her concerns were partly about wanting to spend more time with her grandchildren. As she put it, 'I should be at home with the grandchildren. I shouldn't be here in an office'. Retirement offered much more than grand-parenting. Not only did she talk about participating in the Ramblers' Association and Scottish country dancing, Mrs I was also positive about her post-work life: 'I would say our lifestyle has improved, because, well, when you were working you couldn't get the time off to do anything much, and we have spent a lot on holidays'.

Dissatisfaction with work was not the only reason for accepting early retirement packages. Some, such as Mrs L, a messenger, enjoyed their work but wanted to get more out of life. She had taken up driving at 59 years of age and in the week of the interview was to take her driving test. Explaining her decision, she said:

I mean, I've always envied people, you know, when I've seen ladies just jumping in the car and off they go, and I thought to myself, shall I have a go at that? 'No, I won't. Not at 59, I'm too old.' And then I thought, 'no, I'm not going to say that I'm too old: I'm going to have a go'. So I sent away for a provisional licence (laughs) and I started in September, and as I say, I've got my test on Thursday.

Mrs L described herself as 'a lady of leisure really' and focused on the essence of the third age. For her the main difference in her life in retirement 
was that, "when you are working you have to do the job, when you retire, you do what you want to do, you haven't got to do anything have you really'.

\section{Work dissatisfaction exit}

This ideal type describes those who leave as a result of dissatisfaction with work. Several respondents did not like the changes brought about by the reorganisation of the civil service. $\mathrm{Mrs} \mathrm{H}$, a middle-ranking civil servant, had worked in the service for 32 years and had retired early at 57 years of age. She had enjoyed her job until her department was relocated to a different area. This lengthened her journey to work, and she found that she returned home so late that she was unable to continue evening classes. She decided that she was not prepared to spend extra time travelling, and retired early. She had previously twice applied for early retirement and had not been selected. Describing the organisational and technological changes in the civil service, she said:

Well it is quite stressful that constant change, because you would get used to one thing and then it would change to something else. The methods would keep changing - roles would keep changing - I mean even the technical side kept changing, and it still is. I mean, I was talking to someone only on Saturday, who is still there and he was saying, you did the good thing, didn't you, getting out.

Others such as Mrs E, a clerical worker, decided not to stay in their job even though she was asked to stay another year. She cited the impact of computerisation as the main reason why she left after 2I years:

I know I was quite pleased to get out of it because they went on computer and I'm afraid I'm not very good with computers (laughs). I don't like computers very much. I mean I used to do it, you know, and we had, we had to learn about it, but if it went wrong, I was always shouting help!

\section{Poor health exit}

This ideal type refers to someone who leaves work because of their own illhealth or disability, or because someone they were responsible for was ill or disabled. Retirement on the grounds of ill-health is funded by The Treasury. Consequently, very few civil servants are retired on these formal grounds. Some whose health was suffering used other routes to stop working early. $\mathrm{Mr} \mathrm{H}$, a middle-ranking civil servant who suffered from claustrophobia which made him very anxious when travelling to work by train, took early retirement at $5^{8}$ years of age:

With the old [carriage] doors, if I needed to, I could get down on the track, but the new ones you can't open and I feel trapped and I found that very stressful, and travelling by train was getting worse. 
Most respondents with ill-health (some reported a long-standing illness) said that ill-health and caring responsibilities had not pushed them into early retirement, although others said that retirement at 6o was welcome. Mrs N, a senior civil servant, had worked in the service for Io years, had suffered a long-term illness for 30 years, while her husband, for whom she was the main carer, also had a chronic long-term illness. She could have asked to work longer than the mandatory retirement age (because her short service meant that she did not have a full pension entitlement) but she chose not to. She did not cite health as a reason for wanting to retire, although she knew it would be an issue in the future. She explained:

If I had been given the opportunity to stay on, I wouldn't have done it, because I am now certain that there are situations which have got to be faced up to at home, and we have been living on a knife-edge in terms of my working. ... I don't make a general thing of it in the office, but it is known that I think that I have [chronic condition], and certainly everyone knows that I have got a problem. I used to be completely mobile and now I am going round with a stick, and therefore there aren't the pressures, to, for example, go to Brussels, or to go away etc. And I don't feel that I could, so to speak, say that, yes, I want to continue for another five years, if I wasn't prepared to go away, and I would just worry now. I mean the times I have actually been away, I am certain my husband has been absolutely fine, he's coped perfectly alright.

\section{Connections between ideal types}

In presenting the ideal types, the complexity of the decisions facing many civil servants as they came up to retirement age has been illustrated. The change in the civil service over time, and the various packages on offer, make every individual's situation and choice unique. Consequently, some members of the sample cross-cut the ideal types, some because the periods of early retirement were quite short given the time to process their applications. Another factor is that the mandatory retirement age at the time was 60 years (which for men was five years earlier than the age of entitlement to a state old age pension). Some respondents retired at the normal civil service retirement age of 60 even though dissatisfied with their work. Mrs E decided not to continue in her clerical job after 6o years of age even though she could have done so, because of the new technology and the need to retrain to keep up. Others enjoyed work and did not want to take early retirement although they could be seen as enjoying all the attributes of the third age. $\mathrm{Mr}$, a retired senior civil servant, organised his life around his yacht, and could have retired early on account of his overseas service, but he chose to stay on until 6r years of age and only left 
because he felt that he was 'in other people's way'. The ideal types were developed to help us to understand the forces operating on civil servants rather than to be exhaustive of all their individual decisions.

\section{Discussion}

Some commentators have suggested that until the Ig8os a common view was that early retirement was connected to ill-health (Parker I982). During that decade, however, it became apparent that personal financial security was a prime factor in making early retirement decisions. In the United States, Kingson $(1982 a, 1982 b)$ argued that poor health was the over-riding consideration, while Myers ( $1982 a$, I982 $b$ ) maintained that economic factors were most influential, as individuals reacted to national and corporate incentives. Myer's use of sensitive health indicators that took into account morbidity and health-limiting conditions led him to declare that economic variables played a more important role than health in early retirement decisions (Bazzoli 1985). Others showed that ill-health had a significant influence (McGoldrick and Cooper I988; Diderichsen and Janlert I992). Two models of early retirement emerged. In one, pertaining mainly to white-collar professional and managerial workers, the early retirement decision was dependent on a favourable economic outcome. In the other, more associated with manual occupations, the central feature of early retirement was adjustment to, and reconciliation with, a breakdown in physical health (McGoldrick and Cooper i988; Diderichsen and Janlert I992; Astrand, Isacsson and Olhagen 1988).

In accordance with the model for early retirement from white-collar positions, there was in our interviews a conspicuous lack of discussion of ill-health as a factor in the early retirement decision. None of the interviewees referred to physical ill-health directly, and when health problems were mentioned, they were generally described in terms of stress, most often attributed to adverse conditions in the work environment. It is possible that these results reflect a new pattern of early retirement in which mental health as well as economic considerations feature in the early retirement decision among white-collar workers. During the later ig9os, stress-related early retirement became increasingly common among teachers and other professionals involved in the direct provision of public services (Keel I993). Changes in the demands upon and expectations made of civil servants may have extended this pattern into wider areas of the public sector such as the civil service.

Quantitative data, collected as part of the Whitehall II Study, reinforce this conclusion and suggest that the last occupational grade affects health 
in retirement even when health at work is controlled (Hyde et al. 2002). These results not only demonstrate the persistence of health inequalities in retirement but also point to the significance of the stresses and strains that build up during working life. Lower grade civil servants have less control and autonomy than those higher in the hierarchy, and they are exposed to greater stress and potentially worse health. Consequently, stress is identified as a reason to retire but is not seen by the respondents as ill-health.

\section{Structured dependency versus the third age}

The sociological discussion of retirement and later life has concentrated on two themes: the structured dependency of older people in Britain and the United States versus the existence of a 'third age'. Structured dependency theory sees retirement as a structurally-derived phenomenon created by the need for mass labour market exit in rapidly changing economies. This had been recognised by earlier 'disengagement' theorists, who realised that retirement from paid employment left older people without either status or role. Structured dependency writers argued that the disadvantaged circumstances that older people found themselves in were neither about 'mutual withdrawal' from society nor the accidental effects of social policy. Rather, writers such as Townsend (I98I), Walker (I98I), Phillipson (I990), Vincent (I995) and Estes (I979) were at pains to point out that low status and poverty were the inevitable outcomes of making the retired 'structurally dependent' on pensions or welfare benefits. A key factor in this process was the low level at which pensions (particularly state pensions) or welfare benefits were set.

The important implication for the findings presented here is that a structural rationale may explain why retirement is not sought by many workers, especially those at the lower end of the employment grade structure. As Hyde et al. (2002) have pointed out, it is unsurprising that, as with health, the financial outcomes of retirement reveal continuities between working life and retirement. Those who are well-off at work tend to be well-off in retirement. Attempts to encourage less well-off workers to take early retirement often promote a transition into a worse situation. As many writers have pointed out, the use of early retirement to 'downsize' an organisation is likely to have a negative effect on the participants' postwork life.

Among our respondents were individuals who had resisted the offer of early retirement because it would only have led to a worsening in their finances. Mr J described the early retirement 'offer' as attractive but said that he liked the standard of living he had when working, and also that he had two financially-dependent children at university. Others accepted the 
offer because it solved a current financial difficulty, but were under no illusions as to their fate once they had left the workforce. For example, Mr D, who shortly before the interview had taken out a mortgage that committed him to repayments until 75 years of age, accepted the retirement package because it provided a lump sum. There were others for whom the civil service career structure offered stability in their lives that would disappear after retirement, and this was the basis of resistance to offers of early retirement. Mr A, a senior civil servant, who retired at the normal time, put it like this:

But my apprehension was that I wasn't going to be as happy retired as I was working. Not because of the pressure but because I enjoyed work. It wasn't the unknown - it was just I felt that life was not so satisfying without work because work had become a big part of life.

The other main construction of retirement can be generalised as the 'third age'. As stated earlier, this position is most closely associated with the treatise developed by Peter Laslett (I989, I996), which presents retirement as far from negative and an opportunity for the 'crown of life'. Drawing from diverse evidence on population ageing, improved health and the spread of prosperity, Laslett argued that during post-work life, individuals are free to pursue their own projects and enrich society in the process. While Laslett's position was the most fully elucidated and was based on the British experience, American writers have elaborated similar themes. Their approach has been more materialistic and more focused on the experiences and wealth of the 'baby boomer' generation (born roughly between I945 and I965), but reaches similar conclusions about the potential of later life (see Gilleard and Higgs 2002).

To these positions must be added writers concerned with the break-up of the stable lifecourse, such as Featherstone and Hepworth (I99I), Giddens (I994) and Vincent (2003). For them, the greater reflexivity of society means that later life can no longer be considered a residual category. Instead, the lack of age stratification and the retreat of the welfare state may lead many older people into a more engaged lifestyle. Leisure pursuits can be enjoyed across a wide age range, and an individual's financial resource need not be dependent on the generosity of the government. Affluence may only be experienced by a minority of the retired, but there were exemplar individuals in our sample. They saw early retirement as a positive option. Being able to give up work with an adequate income allowed them to engage in the things that they enjoyed and which motivated them. Such considerations played a role in encouraging others to contemplate early retirement packages. The size and nature of the financial package was crucial in making their decision, but the prospect 
of not working for the civil service and of being able to do the things that they enjoyed also had an impact. For example, Mr O, a middle-ranking civil servant, was so dissatisfied with his job that when the early package offer arrived he accepted it. He said in relation to others who had taken early retirement:

Yes, [all the others] had gone, at the best time of their lives and I thought, hang on, I'm missing out on this!

The different reactions to the possibility of early retirement emphasises the importance of attention to the circumstances and prospects of those in different occupational grades. Hyde et al. (2002) reported that coming from the lower occupation grades has a negative effect on both health and the number of activities pursued.

\section{Were they pushed, did they jump, or did they choose?}

The proposed ideal types were derived from the respondents' reactions to the process of early retirement. Their responses can be further analysed in relation to three questions: Were they pushed? Did they jump? Did they choose? The questions throw light on how the decisions made by each respondent were reached, and imply a typology of cases. The distinctions among the three types are not absolute, but each category provides valuable explanatory utility. By being 'pushed' is meant that the offer of early retirement was accepted because it exploited a respondent's dissatisfaction with some aspect of work. Maybe the job description had changed, or work had become very stressful. Alternatively, it could be that an immediate need for money overcame a long-term disadvantage. Indeed, it could be that the package was not large enough to facilitate early retirement and the stressful conditions had to be endured until normal retirement.

'Jumping' refers to those whose acceptance of early retirement was mainly motivated by the nature of the package. This can be in terms of its monetary attractions, as with 'I'd be silly not to' or 'I might not get this opportunity again', or because the individual had made plans such as for alternative work. Those who can be said to 'choose' either continued working for positive reasons, or early retirement, did so to follow their interests. The act of 'choosing' may have involved a partial rejection of purely financial considerations in their decision-making. These three labels for the different influences and responses to the decision-making process reflect a deeper set of sociological concerns, namely the roles played by structure and agency in social processes: it is to these issues that we now turn. 


\section{Structure and agency}

The terms structure and agency have a long history in the social sciences and refer to the relative roles of social determinacy and individual choice and action (Giddens 1979). There are many different formulations of this relationship (see Walsh 1998 for a discussion). No particular approach is advocated here, except that there is always a tension between the two levels of social reality. Structures may influence an individual's actions, but individuals in turn influence the nature of structures. Without individual agency in the early retirement decision, it would simply be redundancy. In a similar fashion, without an early retirement policy it would be impossible to restructure the civil service except by mass redundancies. As such a policy was unacceptable, the interplay between structure and agency became important.

In this study, the financial offer to retire early exemplifies the action of structure. The financial inducement is clearly intended to produce exits from employment in order to restructure the workforce. Who is offered packages and what they comprise are adjusted as the employer ascertains just how much pressure is needed. The operation of such structural pressure is revealed by determining who is 'pushed'. The calculation can be made that the money offered as well as freedom from the job will be decisive. The leaving group have limited room for manoeuvre, although the choices facing those who 'jump' are distinctive. The precise form that the offer takes makes all the difference; the better the package the better the response to it. This could be seen as the operation of structure on the individual, but could also be seen as the exercising of a certain amount of agency - how to get the best possible deal becomes paramount.

Agency in these circumstances could also be identified as choosing not to do what is wanted of individuals. For those who 'choose' to remain working it could be that the nature of the early retirement package plays little role. Those who stay because of their identification with their job, and for whom no package is acceptable, are exercising agency (although it is recognised that the distinctions between the categories may be blurred). Individuals wanting to change life direction by retiring early may be influenced by the packages on offer, but may have already taken the decision to leave regardless of the offer. They sign up to what they see as a windfall or bonus. Those who leave because of the package may also find that they are enabled to pursue interests that had not played any role in their decision-making.

This discussion of the relationship between structure and agency tells us that the motivations for early retirement need to be seen as more than a simple economic judgement. The money on offer for early retirement is 
not the only factor influencing decisions. Agency also plays a role and needs to be taken into consideration. This is particularly important when the cultural space that is opened up by the third age is taken into account. Retirement is no longer necessarily a period of decline, dependency or disengagement: rather it can be seen as a positive choice, to leave the responsibilities of Laslett's 'second age' of work and child-rearing.

\section{Conclusions}

This paper has provided evidence of the different responses that civil servants have made to the opportunity for early retirement. While, for some, retirement is still a structured aspect of their working lives, for others early retirement offers opportunities for either self-fulfilment or escape from the pressures of an increasingly fraught work environment. It is interesting to note that in these circumstances, the direct influence of ill-health is comparatively rare.

Three ideal types have been proposed to describe the selected biographies. Each illustrates aspects of the changing nature of later life that, as Gilleard and Higgs (2000) have pointed out, is increasingly fragmenting. The stable lifecourse that had retirement as a final stage is becoming an option in the United Kingdom and elsewhere. Even the civil service, for long regarded as the epitome of life-long employment, has witnessed these changes. Retirement followed by lucrative alternative employment has long been an option for the highest grades, but early retirement packages had made many others aware that they had options, many of which were consistent with third age activities and actualisation rather than pure economic expediency. Another dimension that has been considered is that of agency. The route to early retirement taken by many is the 'good package'. Does accepting one reflect bribe, freedom or coercion? This question needs to be addressed when we think through the implications of early retirement for society. The policy of early retirement may manifest the necessity for structural changes in the workforce but at the same time might provide the impetus for the reordering of later life. What happens to those who wish for the old certainties of the lifecourse is another aspect of earlyretirement that needs to be addressed.

\section{Acknowledgements}

The work for this paper was funded by a research grant from The Nuffield Foundation. The Whitehall II study was supported by grants from the Medical Research Council, the British Heart Foundation, the Health and Safety 
Executive, the Department of Health, the National Heart Lung and Blood Institute (HL363Io), the United States National Institute on Aging (AGi3I96), the United States Agency for Health Care Policy Research (HSo65i6); and the John D. and Catherine T. MacArthur Foundation Research Networks on Successful Midlife Development and Socio-economic Status and Health. We also thank all those who participated in the Whitehall II study and all members of the Whitehall II study team.

\section{NOTES}

I Informed consent was obtained. The interviews were tape-recorded and transcribed. The responses were then indexed by the themes that arose from the interviews and organised using the QSR NUD.IST qualitative data analysis computer programme (Non-Numerical Unstructured Data Indexing Searching and Theory-Building 1995).

2 Under erstwhile contribution rules, married women were not allowed to participate in the civil service occupational pension scheme.

\section{References}

Astrand, N.-E., Isacsson, S.-O. and Olhagen, G. O. I988. Predictors of early retirement on the basis of a health examination. Scandinavian Fournal of Work Environmental Health, I 4, IIO-7.

Bazzoli, G. J. 1985. The early retirement decision: new empirical evidence on the influence of health. Fournal of Human Resources, 20, 2I5-34.

Becker, H. I998. Tricks of the Trade: How to Think About Your Research While Doing It. Chicago University Press, Chicago.

Blaikie, A. 1999. Ageing and Popular Culture. Cambridge University Press, Cambridge.

Diderichsen, F. and Janlert, U. I992. Effects of economic change on male morbidity in neighbouring industrial and rural municipalities in northern Sweden. Fournal of Epidemiology and Community Health, 46, 605-7.

Estes, C. 1979. The Aging Enterprise. Jossey Bass, San Francisco, California.

Featherstone, M. and Hepworth, M. I99I. The mask of ageing and the postmodern life course. In Featherstone, M., Hepworth, M. and Turner, B. (eds), The Body: Social Process and Cultural Theory. Sage, London, 371-89.

Foster, C. and Plowden, F. 1996. The State Under Stress. Open University Press, Buckingham.

Giddens, A. 1979. Central Problems in Social Theory. Macmillan, London.

Giddens, A. 1994. Beyond Left and Right: The Future of Radical Politics. Polity, Cambridge.

Gilleard, C. and Higgs, P. 200o. Cultures of Ageing: Self, Citizen and the Body. Prentice Hall, Harlow, Essex.

Gilleard, C. and Higgs, P. 2002. The third age: class, cohort or generation? Ageing and Society, 22, 369-82.

Government Statistical Service 1997. Civil Service Statistics 1997. Her Majesty's Stationery Office, London.

Government Statistical Service 1999. Civil Service Statistics 1999. Her Majesty's Stationery Office, London.

Higgs, P. I999. Quality of life and the changing parameters of old age. Aging and Mental Health, 3, I97-8.

Hyde, M., Ferrie, J., Higgs, P., Mein, G. and Nazroo, J. 2002. The effects of pre-retirement circumstances and retirement route on circumstances in retirement: findings from the 
Whitehall II study. Paper prepared for Department of Epidemiology and Public Health, University College London.

Keel, P. I993. Work-related emotional-stress: the burnout-syndrome. Sozial-und Praventivmedizin, 38, Supplement 2, Si3 ${ }^{-2}$.

King, R., Warnes, A. M. and Williams, A. 2000. Sunset Lives: British Retirement Migration to the Mediterranean. Berg, Oxford.

Kingson, E. R. I982a. Health and the early retirement decision. Ageing and Work, 5, 2, 93-IIO.

Kingson, E. R. $1982 b$. The health of very early retirees. Social Security Bulletin, 54, 9, 3-9.

Laslett, P. I989. A Fresh Map of Life: The Emergence of the Third Age. Weidenfeld and Nicholson, London.

Laslett, P. 1996. A Fresh Map of Life: The Emergence of the Third Age (second edition). Macmillan, London.

Laczko, F. and Phillipson, C. I99I. Changing Work and Retirement. Open University Press, Buckingham.

Marmot, M. G., Davey Smith, G., Stansfeld, S. A., Patel, C., North, F., Head, J., White, I., Brunner, E. and Fenney, A. I99I. Health inequalities among British civil servants: the Whitehall II study. Lancet, 337, I387-93.

McGoldrick, A. and Cooper, C. I988. Early Retirement. Gower, Aldershot, Hampshire.

Mein, G., Higgs, P., Ferrie, J. and Stansfeld, S. I998. Paradigms of retirement: the importance of health and ageing in the Whitehall II study. Social Science and Medicine, 47, 535-45.

Mein, G., Martikainen, P., Stansfeld, S., Brunner, E., Fuhrer, R. and Marmot, M. 2000. Predictors of early retirement in British civil servants. Age and Ageing, 29, 529-36.

Myers, R. J. I982 $a$. Health and the early retirement decision debate: why do people retire early from work? Ageing and Work, 5, 39-55.

Myers, R. J. 1982 b. More about the controversy on early retirement. Ageing and Work, 5, IO5-9.

National Union of Civil and Public Servants r991. Agenda for the Future: The Civil Service Towards the Twenty First Century. National Union of Civil and Public Servants, London.

Parker, S. 1982. Work and Retirement. George Allen and Unwin, London.

Phillipson, C. I99o. The sociology of retirement. In Bond, J. and Coleman, P. (eds), Ageing in Society: An Introduction to Social Gerontology. Sage, London, I44-6o.

Phillipson, C. I999. Reconstructing Old Age. Macmillan, London.

QSR NUD.IST (Non numerical Unstructured Data Indexing Searching and Theorybuilding) I995. Melbourne, Australia.

Townsend, P. I98I. The structured dependency of the elderly: a creation of social policy in the twentieth century. Ageing and Society, I, 5-28.

Vincent, J. 1995. Inequality and Old Age. UCL Press, London.

Vincent, J. 2003. Old Age. Routledge, London.

Walker, A. i98I. Towards a political economy of old age. Ageing and Society, I, 73-94.

Walsh, D. 1998. Structure/agency. In Jenks, C. (ed.), Core Sociological Dichotomies. Sage, London, 8-33.

Address for correspondence:

Accepted 23 April 2003

Paul Higgs, Centre for Behavioural and Social Sciences in Medicine, University College London, Wolfson Building, $4^{8}$ Riding House Street, London WIN 8AA.

Email:p.higgs@ucl.ac.uk 